Global Conferences Series:

Social Sciences, Education and Humanities (GCSSSEH), Volume 3, 2019

The $1^{\text {st }}$ International Conference on Education, Social Sciences and Humanities

DOI: https://doi.org/10.326/hum0224

\title{
The Effect of Future Expectations on Student Motivation in Pancasila and Citizenship Education (PPKn) Study Program at Higher Education in the city of Padang, West Sumatra
}

\section{M.Nursi}

Universitas Bung Hatta, Padang, Indonesia

m.nursi01@gmail.com

\begin{abstract}
The condition of "deteriorating learning spirit" for most students in the Pancasila and Citizenship Education (PPKn) study program in Padang City currently makes us worry about the quality of graduates, moreover they will face challenges in various symptoms of "moral decline" among students like low ethics immoral behavior, promiscuity, violence, pornography, fights, and so on. This study aims to reveal how strong PPKn students are committed to their future, focusing on the influence of future expectations as PPKn teachers on learning motivation. This study (2018) used a quantitative approach with a cross sectional survey. After testing the instrument, then with and with the questionnaire, 217 samples (43.5\%) were conducted with the pre-survey stage. The results of data processing show that the highest achievement of the ideal score is "the basis of" selection of study programs/professions "is $77.03 \%$ (sufficient), while the lowest indicator is" expected implications "of 58.31\% (less). $50 \%$ (enough). These findings can be interpreted as stronger future expectations / student ideals, the stronger the motivation to learn.
\end{abstract}

Keyword: student motivation, PPKn

\section{Introduction}

Since a few years ago until now there has been a tendency for most students in general and for students of the Pancasila and Citizenship Education Study Program (PPKn) in universities in the city of Padang in particular the emergence of symptoms of lethargy or decline in the spirit of learning. This symptom encourages us to question the motivation of his studies. It is difficult to deny that lectures with the chosen PPKn study program, which will later become PPKn teachers are their own future hopes,

Copyright (C) 2019, the Authors. Published by Redwhite Press.

Page | 247

This is an open access article under the CC BY-NC license

(http://creativecommons.org/licenses/by-nc/4.0). 


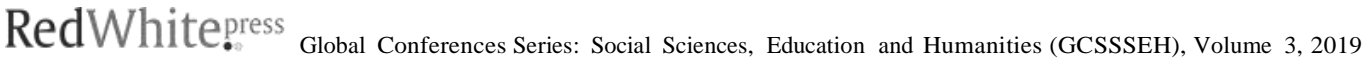

which should actually be addressed with strong motivation. The strong problem or the lack of motivation to learn / college students is basically inseparable from the root of the problem, namely the condition of the expectation of the future (being a teacher of PPKn).

Therefore the purpose of this study is to reveal how the future expectations of PPKn students influence their learning motivation. This problem is important to study, especially when they become teachers of PPKn, they will face the challenges of the attitudes and behavior of most students of the First Middle School (SLP) and High School (SLA). At this time, there are increasingly symptoms of various attitudes and behaviors that are increasingly distant from the guidance of religious, ethical and moral values. We can see this or we look through the news in various mass media, such as the occurrence of acts of violence, including rounding off between students, students with teachers, brawls between schools, promiscuity and even free sex, pornography, drugs, and so on. All of these symptoms basically reinforce the indication of the diminishing ethical and moral awareness of the students. Thus there is a kind of counter productive condition that is the motivation of most PPKn students who tend to weaken. Then the condition is antagonistic with the increasingly widespread symptoms of moral deterioration among most students both in SLP and SLA which they must face later (Soemantri, 1976: 35).

Candidates for PPKn teachers who will face and should contribute to overcoming these problems among students are the main responsibility that must be realized and borne in the future, as a consequence of their professional responsibilities (Kusuma, et al .: 2011). Therefore, the problems in this study are upstream issues that must be identified and addressed.

Regardless of the matter of consideration of what or the factors that influence students, what is certain is that the lectures on the PPKn study program have been executed as choices and decisions that lead students to their future hopes / aspirations to become professional PKn teachers. Therefore it is logical that students should have a strong motivation to reach their hopes / aspirations (Dariyo, Agoes, 2004). But the question here is, is there any influence on future expectations / ideals on student motivation?

On the basis of these problems, the hypothesis proposed is: there is a significant effect of future expectations / ideals on student learning motivation? The proof of the hypothesis is directed and limited to the analysis of the influence of two correlational variables namely Future Expectations / Ideals (being PPKn teachers) as independent variables, and Learning / Lecture Motivation as the dependent variable.

As a quantitative study (2018), the method used is a correlational survey method, specifically a crosssectional survey with a proportional stratified random sampling technique, and data analysis using regression statistics and ANOVA through IBM SPSS 20.

In connection with research on the influence of future expectations / ideals, (including being a teacher of PPKn) on learning motivation / lecture, as long as the search for writers may be said to be nonexistent. There is even quite a lot of research that examines various other factors (besides future expectations / ideals) that influence learning motivation. Or conversely the influence or contribution of motivational factors on learning outcomes in various versions. As an example of research traced, among others, are research: (1) Latief Sahadin and Dini Jamil, "The Effect of Motivation on Achievement and Student Perception of the Way Teachers Teach Against Mathematics Learning Results" (Journal of Mathematics Education, Vol. 4 No.2, July 2013), (2) Ridaul Inayah, et al., "The Effect of Teacher Competence, Student Learning Motivation, and Learning Facilities on Learning Achievements in Economic Subjects in Class XI Social Studies Students of State 1 Lasem Jawa Tengah 2011/2012 Academic Year", FKIP Journal Sebelas 


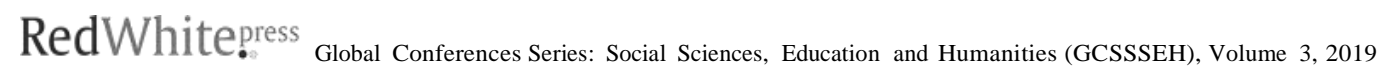

Maret University Surakarta, Vol. 2, No.1 Th. 2013, (3) I Wayan Dwija, "Relationship Between SelfConcept, Motivation, and Attention of Parents with Learning Outcomes of Sociology in Class 2 Students of Amblapura Public High School", Journal of Education and Education, Vol. 41 No.1 (2008), (3) Ira Nofita Sari, "The Influence of Interest and Learning Motivation on Physics Learning Achievement in Class XI Students of Natural Sciences 1 Galing Sambas Regency", Journal of Mathematics and Science Education (JEMS), Vol. 4, No. 2, September 2016, (4) Aritonang, "Interest and Motivation in Improving Student Learning Outcomes", Journal of Education Sower, No. 10, Th. 7th, June 2008, and others.

Research that is relatively close, among others, is Christin Umar's research: "Effect of Teacher Expectations on Student Motivation and Achievement in Classes, Economic Development, Scientific Magazine, Faculty of Economics Unparoo, 106 Volume 14, Number 2, August 2010. The findings reveal that teacher's expectation positivity towards students can be a reinforcement for students to achieve higher performance.

In line with Christin Umar's research, by Lisniawati conducted a study on the Effects of Giving Hope and Incentives on Student Learning Motivation in Indonesian Language Learning (Journal of Indonesian Language and Literature Research, Literacy, Volume 1, No.1, 2017). The study of students of Cijantung Ciamis MAN also proved that giving hope (X1) and Incentives (X2) to students also affected students' learning motivation $(\mathrm{Y})$.

Akhid Rifqi Rokhim, Dkk. (2013) with the title Relationship between Learning Motivation and Future Optimism in Twinning Program Students at Muhammadiyah University Surakarta. His findings indicate that student learning motivation significantly influences future optimism, which is statistically proven by the value of the correlation coefficient ( $r$ ) of 0.688 greater than the $p$ value: $0,000(p<0.01)$. Therefore, the higher the motivation for students to learn, the higher their future optimism, the lower their learning motivation, the lower their future optimism. From the results or findings of the related studies above it can be affirmed that factors or variables "expectations" generally and "future expectations" in particular have an influence or contribution to the development of student and student learning motivation.

In line with the results or findings of these studies, the research findings that the authors / researchers did also prove that future expectations / aspirations (being PPKn teachers) have a significant effect on the learning motivation of PPKn Study Program students in universities in Padang City.

\section{Method}

As quantitative research, the study was conducted in the odd semester of the 2017/2018 academic year, April and May 2018, using a cross sectional survey method, conducted on a population of 499 students, consisting of 445 students from Padang State University PPKn students, and 54 people at PPKn study program FKIP Bung Hatta University, with a total sample of 217 (43.5\%). Sampling using Proportional Stratified Random Sampling technique. While the data is obtained and by using a structured and closed questionnaire technique, or using a Likert Scale model. The contents are synchronized statements with variables and research indicators developed with a range of weights 1 to 5 .

The research is generally carried out through pre-survey steps, instrument trials, data collection, data processing and analysis, and writing research results. But first developing the instrument is through: (1) preparation of research variable indicators, (2) preparation of instrument lines, then making inventory models in the form of temporary questionnaires, then undergoing justification by competent lecturers 


\section{RedWhite. ${ }^{\text {press }}$ Giobal Conferences Series: Social Sciences, Education and Humanitites (GCSSSEH), Volume 3, 2019}

and through discussions with colleagues, (3) conduct instrument testing on the shadow subject of the research sample, (4) and test the validity and reliability of the instrument.

Before the actual research, a questionnaire trial was conducted on shadow class (non-sample) PPKn FIS students on April 6, 2018. Initially the number of statements was 35 items, but after being validated, the number decreased to 32 points, which included: (1). the basis for the selection of study programs / professions, (2) interest in the PKn teaching profession (3) pride in PKn teacher status, (4) PKn professional teacher incentives (5) commitment to the PKn teacher profession and completion of studies, and (6) expected implications. Whereas the learning motivation variable which originally numbered 20 changed to 17, which included the

following sub: (1) perseverance in facing the challenges of college, (2) perseverance in going to college, (3) interest in attending college, (4) self-confidence in going to college, and (5) persistence or fighting power.

Validity test uses Product Moment correlation analysis, while the reliability test uses Cronbach Alpha test, with an alpha significance level of 0.05 , meaning that if the results of the validity count show a probability smaller than 0.05 then the related statement item is declared valid and valid. And for the reliability test (RTT), if the RTT is greater than $r$ table with an alpha significance level of 0.05 , the questionnaire items are declared reliable and reliable.

The criteria for determining the instrument are valid, so the interpretation criteria for the correlation index (r) are seen, namely: $0.800-1,000=$ Very high, $0.600-0.799=$ high, $0.400-0.599=$ quite high, 0.200 $0.399=$ low, and $0.600-0.199=$ very low (invalid). (Sugiyono, 2007).

The next step for processing data is the steps or procedures as follows: (1) selecting data so that it can be further processed, namely by examining the respondent's answers according to established criteria; (2) determine the value weight for each possible assessment that has been determined, then determine the score; (3) conduct descriptive analysis, to determine trends in data such as mean, median, standard deviation, and data variance of each variable; and finally (4) conduct regression tests and ANOVA with the help of Statistical Product and Service Solutions (SPSS) program version 20.

\section{Results and Discussion}

From the statistical test using the SPSS version 20 program, the results of the study showed that the hypothesis was accepted, because from the results of the ANOVA analysis it was proven that the probability value (Sig) was 0.001 . Because the Sig value is $0.001<0.05$ with the decision Ho rejected and Ha accepted. That is, future expectations / aspirations (being PPKn teachers) (X) significantly influence learning motivation $(Y)$. while the effect coefficient is 0.215 with the values $t=3,235$ and Sig. 0.001 which is smaller $(<)$ than $\alpha 0.005$. That is, future expectations / ideals significantly influence student motivation at 0.215 . This finding can be interpreted as the stronger future expectations / ideals of students, the stronger the motivation to learn.

The conclusion statement of this hypothesis is a fact of psycho-social found through this research. In addition to being very logical, the quantitative proof above is supported or related to various theories about "hope" where learning or study activities are supported by the overall ability and optimally owned by the individual concerned to realize his expectations. 


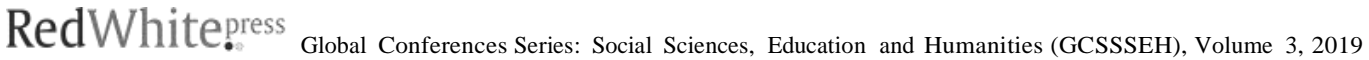

Because of that future hopes / ideals contain and / or generate energy as a motivation that moves individuals to take steps or efforts that will or have been produced. In line with the findings of research by Christin Umar (2010), Lisniawati (2017) and Akhid Rifqi Rokhim, et al. (2013) stated earlier that in its substance there is an effect of "hope" on learning motivation.

Considering the significant influence of future expectation variables (being PPKn teachers) on college motivation, students or prospective students need to be developed or reinforced the awareness or commitment of students towards their future hopes of becoming PPKn teachers. The initial step can be done by doing a psychological test to detect or identify conditions of awareness or commitment to future expectations / aspirations to become a PPKn teacher, especially for prospective students. Therefore to foster strong college motivation, it is necessary to socialize "lecture awareness" to students, especially from the study program leadership, starting at the initial moment of acceptance or at the beginning will begin lectures such as through Ospek, and then periodically during the lecture bench. Such socialization may also be delegated through lecturers and / or special programs for academic advisors (PA).

\section{Conclusion}

It can be concluded that in order to obtain a great opportunity for a student to have a strong motivation to complete his studies or study, it is logically necessary to strongly convince the related students to have adequate understanding, positive perceptions and great expectations for the study program and / or profession to choose. And be far from the environmental influences of friendship, especially the will of parents.

\section{Reference}

Dariyo, Agoes. (2004). Pengetahuan tentang Penelitian dan Motivasi Belajar untuk Siswa. Jurnal Psikologi, vol 2, no. 01 Juni 2004

Kusuma, Darma, dkk. (2011). Pendidikan Karakter Bandung: PT Remaja Rosdakarya.

Lisniawati. (2017). Pengaruh Pemberian Harapan dan Insentif terhadap Motivasi Belajar Siswa dalam Pembelajaran Bahasa Indonesia (Jurnal Penelitian Bahasa dan Sastra Indonesia, Literasi, Volume 1, No.1, 2017).

Rokhim, Akhid Rifqi, dkk. (2013). Hubungan antara Motivasi Belajar dan Optimisme Masa Depan pada Mahasiswa Program Kembar di Universitas Muhammadiyah Surakarta.

Sugiyono. (2007). Metode Penelitian Pendidikan Metode Kuantitatif, Kualitatif, dan R\&D, Bandung: Alfabeta.

Soemantri, N'Uman. (1976) di (www.One.Indos encrypt.com).

Umar, Christin. (2010). Pengaruh Ekspektasi Guru terhadap Motivasi dan Prestasi Siswa di Kelas, Perkembangan Ekonomi, Majalah Ilmiah Fakultas Ekonomi Unparoo, 106 Volume 14, Nomor 2, Agustus 2010.

Undang-Undang Sistem Pendidikan Nasional No.20 tahun 2003

Uzman, Moh. Uzer. (2010). Menjadi Guru Profesional. Bandung: Remaja Rosda Karya 